\title{
VIBRATION PROPERTIES OF STEEL CONSTRUCTED HOSPITAL ELEVATED HELIPADS
}

\author{
Wiesław Krzymień, Michał Szmidt, Sławomir Cieślak \\ Łukasiewicz Research Network - Institute of Aviation, Al. Krakowska 110/114, 02-256 Warsaw \\ Wieslaw.Krzymien@ilot.lukasiewicz.gov.pl•ORCID: 0000-0001-6758-2621 \\ Michal.Szmidt@ilot.lukasiewicz.gov.pl•ORCID: 0000-0001-7995-594X \\ Slawomir.Cieslak@ilot.lukasiewicz.gov.pl•ORCID: 0000-0003-0100-6837
}

\section{Abstract}

Polish Medical Air Rescue helicopters facilitate the rapid transport of patients to large hospitals. The requirements of the space around the helipad and the safety of flight operations mean that hospitals closer to city centers create more elevated helipads than ground-based helipads. The helipads can vary in the way they are constructed and located - depending on the possibilities offered by hospital buildings and their surroundings.

Vibroacoustics Laboratory of the Institute of Aviation measured the vibration properties of some elevated helipads. The goal of this research was to determine the vibration properties of the helipads itself and the transmission of vibrations to the construction of the helipads, the building and its equipment caused by the landing and taking-off of a helicopter.

This article presents some of the results of measurements of vibrations of steel constructed elevated helipads with the use of a modal hammer and while landing and taking-off of a helicopter, as well as comparison of the vibration properties concerning various elevated concrete helipads.

Keywords: elevated helipads, ground vibration tests, vibration measurements.

\section{INTRODUCTION}

Helicopter air transport enables rapid medical assistance to persons affected by accidents or seriously ill. The operating conditions of the Polish Medical Air Rescue are governed by the Polish Act of 8.09.2006. about National Medical Rescue [1] and the Regulation of the Minister of Health on the hospital emergency department (effective from 1.07.2019) [2] and also lays down the requirements for transport time and the general operating conditions of the hospital helipads.

The requirement of a short transport time of the patient determines the location of the helipad to be as close as possible to the hospital - such requirements correspond to the elevated helipads. The elevated helipads may have different structures (e.g. they may be detached or built above a bunk garage), but due to the impact of helicopters, the helipads on the roofs of hospital buildings deserve special attention. There are currently 36 elevated helipads in Poland, of which 28 are located on buildings (Fig. 1.) Due to the efficiency of the Polish Medical Air Rescue an increase in the number of new elevated helipads at hospitals close to the city center can be expected. 


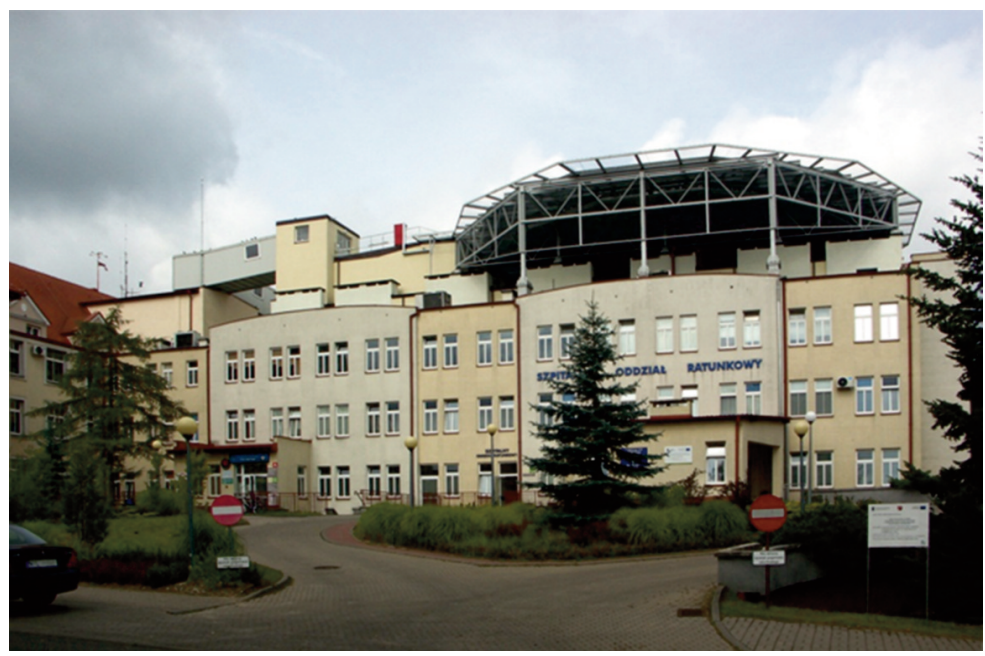

Fig. 1. Helipad on hospital building in Iława [W. Krzymień, 2019].

Elevated helipads on buildings allow to shorten the transport route between the helicopter and the Hospital Emergency Department (SOR). Their disadvantages are: high construction cost, requirements for safe operation, high winter maintenance costs and the possibility of dangerous consequences of a helicopter accident during take-off or landing.

The impact of the helicopter on the landing plate and the immediate surroundings during landing and switching off of the drive and then starting and taking off shall be effected by:

- pulsations of air blowing from rotor blades,

- noise of the engine/engines, rotor blades and tail rotor,

- impulse load from "hard landing",

- vibrations of the main rotor transmitted to the helipad through the landing gear.

The main forces exciting vibrations (transmitted by air under the rotor and by landing gear) are directed vertically. The forces transmitted by the landing gear associated with the deceleration and acceleration of the rotor are directed horizontally or cause a moment relative to the vertical axis. Variable rotational speed of the main rotor and wind can also cause resonant vibrations of the helicopter on the landing gear. Such vibrations are more common for helicopters with fully articulated rotor heads (e.g. Mi-2 or W-3 “Sokól” helicopter). In the case of EC-135 helicopters, the manufacturer has prepared procedures and instrumentation for the tracking of blades and the balancing of the main rotor and tail fan, which ensure that vibrations are minimized over the rotor's entire range of rotational frequencies and their multiples associated with the number of blades. Although these excitations are small, low damping of the helipad's structures can make the helipad vibrate and transmit them to the building [5].

Depending on the technological possibilities and the construction of the building, the helipads above the building may either be concrete or steel structures.

The concrete helipads consist of a heavy slab planted on several concrete columns, which usually are an extension of the structure of the building and thus constitute a uniform structure with it. The top landing plate, which contains the heating system and pipes draining water and fuel (in case of a leakage) can be placed on the elastic and damping layer constituting the vibroinsulation of the helipad. This solution is usually used in the construction of a new hospital building.

Steel helipads are usually of a lighter truss structure (Fig. 2) mounted on dozens of steel pillars with the plate made of duralumin or composite panels containing the heating and drainage systems and the pillars which are placed on vibroinsulators. This solution is used in case of older (i.e. existing) buildings. 


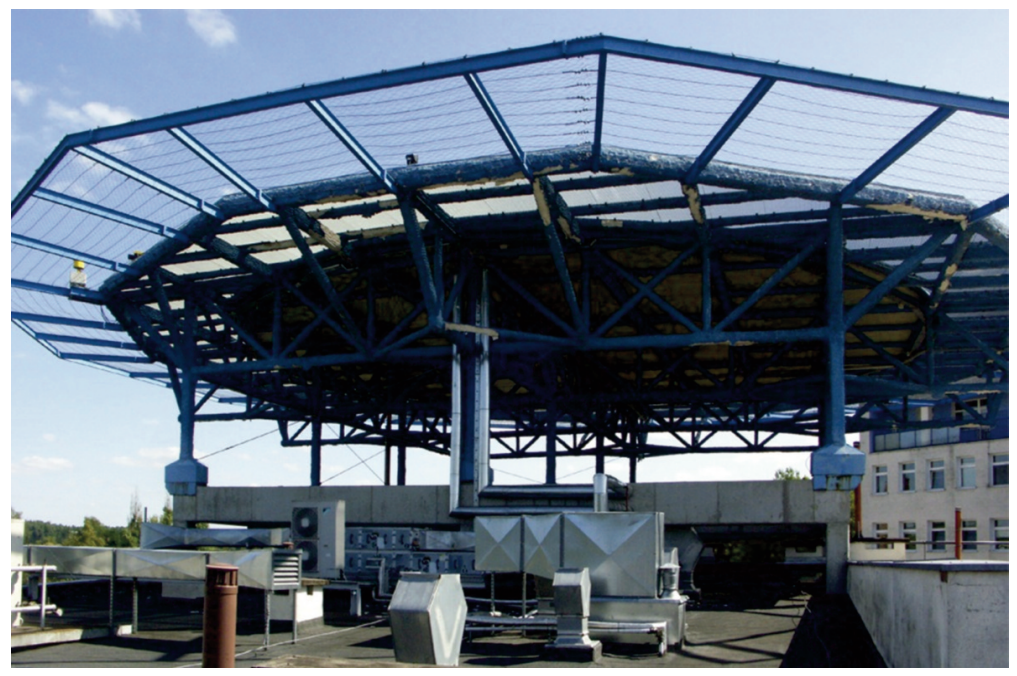

Fig. 2. Part of the steel construction of the helipad in the MSWiA hospital in Olsztyn.

Currently, the required (e.g. by [3]) feature of the construction of helipads is the airgap - the space between the roof of the building and the landing plate, which allows air flow. The airgap requires lifting up of the landing plate and thus reduces the rigidity of the support of the landing plate (in particular bending of the pillars).

The introduced Polish Standard PN-B-02171_2017 [4] defines the measurement method and defines the recommended vibration levels on the floor of different buildings in the area of impact e.g. highways, railways, factories or construction sites. The control measurements should be carried out in the frequency range up to $100 \mathrm{~Hz}$.

The authors of this article made preliminary measurements to estimate the type and size of the impact of the EC-135 helicopter on the environment. This article provides examples of measurements of the vibration properties of steel-based helipads and vibrations transmitted to the building as a result of the impact of a helicopter.

\section{RESEARCH OBJECTS AND MEASUREMENT RANGE}

The vibration measurements of the landings were carried out in three stages:

- the designation of the basic shapes of free vibrations of the helipad,

- assessment of the transferability of vibrations from the landing plate to the floor of the lower storeys of the building,

- measurement of the impact of the helicopter during its landing and take-off.

The third stage was performed only on two helipads.

The research facilities were four elevated helipads:

- helipad S1 - with steel structure, used for several years and supported on 10 pillars set on spring vibroinsulators. The landing plate is located at an altitude of 6 floors.

- helipad S2 - with steel structure, completed, with a square plate located above the roof of the old building and mounted on 44 pillars at a height of 5 floors with rubber spacers as vibroinsulators, - helipad C1 - with reinforced concrete helipad, under construction: designed for the landing of large helicopters. The landing plate is mounted on 9 pillars and is located on the 7 th floor,

- helipad C2 - with reinforced concrete construction, in the finishing phase: a plate with a diameter of $24 \mathrm{~m}$ mounted on 20 pillars and located on the 6th floor. 
The study was conducted using the signal analysis of sensors located on the helipad structure in the range of up to approx. $150 \mathrm{~Hz}$. To determine the vibration properties of the helipad a hammer was used as a vibration exciter (weighing $5.6 \mathrm{~kg}$ - Fig. 3.), acceleration sensors and multichannel measuring system with software to record and analyze response signals.

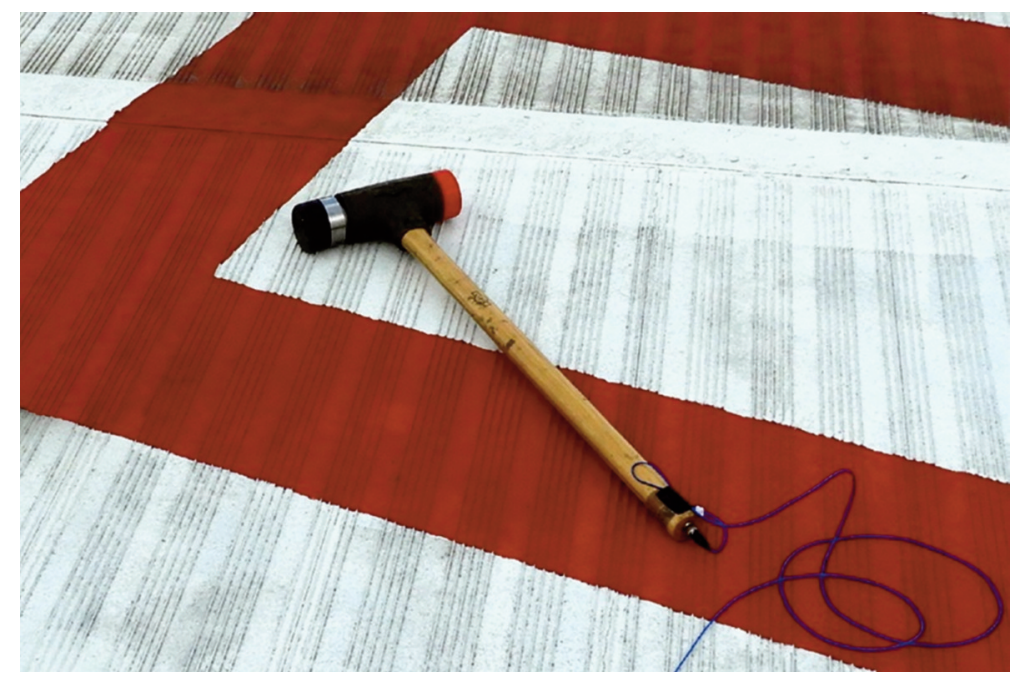

Fig. 3. Modal hammer for impulse exciting of large structures in the center of the helipad.

Testing of the free vibrations of the landing plate (including pillars) after pulse excitation were aimed at determining the basic shapes of vibration at the lowest frequencies. The sensors were placed under the landing plate (inside and near its edge), on the bases of two pillars at the roof level and one sensor on the floor below the roof near the vertical axis of the helipad. Fig. 4. provides an example of two models for visualizing vibration shapes (sensor numbers and their direction of operation are given in nodes). The model in Fig. 4a. was used for steel helipads and in Fig. 4b. it was applied to concrete helipads to help determine the shape of the vibrations the slab transmits on the pillars.

a)

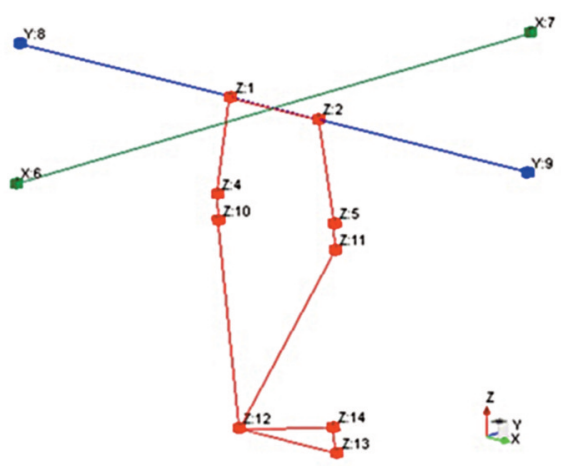

b)

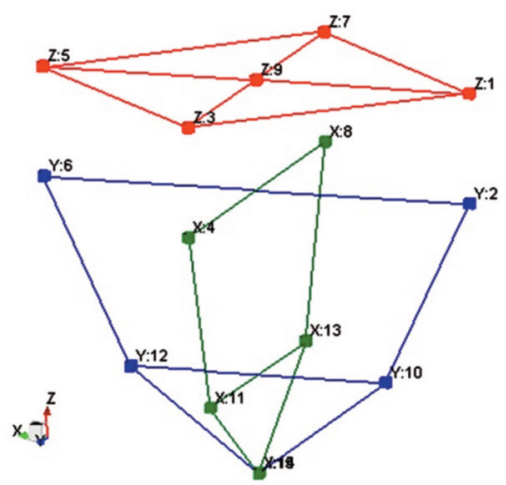

Fig. 4. Two models used to visualize the vibration forms of the tested helipads, $\mathrm{a}$ - steel helipad, b - concrete helipad. 
The tests for assessing the transferability of vibrations from the landing plate to the floors of the lower storeys of the building were carried out with the use of sensors measuring vibrations in the vertical direction which were placed: in the middle of the landing plate and on the lower storeys of the building. An example of the model used to visualize the vibrations of a concrete helipad is illustrated in Fig. 5.

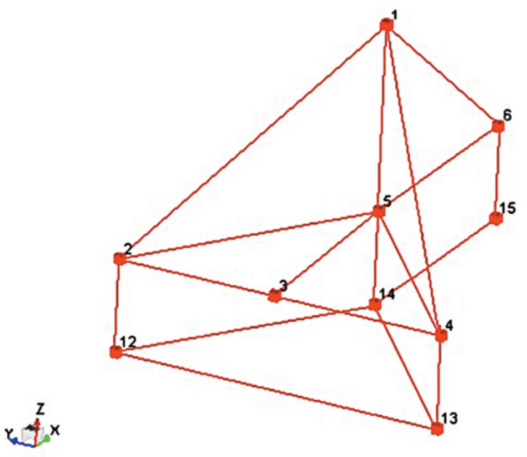

Fig. 5. Model for visualizing and evaluating the vibrations transferred to the building.

The sensors' configuration included measurements of only vertical vibrations: at the landing plate center (sensor No. 1) and on the floor of the lower storey (in the vertical axis of the landing plate and adjacent rooms).

\section{TEST RESULTS}

Table 1. presents the results of the basic vibration shapes, which occurred on all of the test helipads in similar form. The table contains: a description of the shapes, frequency of vibration and relative damping factors $\alpha$ in the range up to $100 \mathrm{~Hz}$. Fig. 6. illustrates two examples of measured vibration shapes.

Tab. 1. A compilation of the basic vibration shapes of the helipad on the building.

\begin{tabular}{|c|c|c|c|c|c|c|c|c|c|}
\hline \multirow{2}{*}{ Lp. } & \multirow{2}{*}{$\begin{array}{l}\text { Description of the shapes of } \\
\text { vibrations }\end{array}$} & \multicolumn{2}{|c|}{ Helipad S1. } & \multicolumn{2}{|c|}{ Helipad S2. } & \multicolumn{2}{|c|}{ Helipad C1. } & \multicolumn{2}{|c|}{ Helipad C2. } \\
\hline & & $\mathrm{f}[\mathrm{Hz}\}$ & $\begin{array}{c}\alpha \\
{[\%]}\end{array}$ & $\mathrm{f}[\mathrm{Hz}\}$ & $\begin{array}{c}\alpha \\
{[\%]}\end{array}$ & $\mathrm{f}[\mathrm{Hz}\}$ & $\alpha[\%\}$ & $\mathrm{f}[\mathrm{Hz}\}$ & $\begin{array}{c}\alpha \\
{[\%]}\end{array}$ \\
\hline 1 & $\begin{array}{l}\text { Rotation of the landing plate around } \\
\text { the vertical axis }(\mathrm{Z})\end{array}$ & 2.1 & 1.0 & 22.7 & 1.9 & 2.47 & 1.3 & 6.8 & 1.6 \\
\hline 2 & $\begin{array}{l}\text { Horizontal vibrations of the landing } \\
\text { plate in the X direction }\end{array}$ & 18.2 & 0.9 & 10.9 & 3.3 & 9.55 & 1.8 & 24.4 & 4.4 \\
\hline 3 & $\begin{array}{l}\text { Horizontal vibrations of the } \\
\text { landing plate in the } \mathrm{Y} \text { direction }\end{array}$ & 19.6 & 1.5 & 12.6 & 2.2 & 11.7 & 3.2 & 30.9 & 1.9 \\
\hline \multirow{2}{*}{4} & \multirow{2}{*}{$\begin{array}{l}\text { Vertical vibrations of the landing } \\
\text { plate }\end{array}$} & 8.5 & 3.2 & 30.4 & 0.3 & 7.07 & 0.7 & 16.3 & 2.4 \\
\hline & & $\begin{array}{ll}17.3 \\
\end{array}$ & 4.4 & 43.2 & 3.4 & 44.2 & 1.4 & 51.6 & 2.1 \\
\hline \multirow{2}{*}{5} & \multirow{2}{*}{$\begin{array}{l}\text { Horizontal vibrations of the landing } \\
\text { plate, vertical vibrations of the plate }\end{array}$} & 44.7 & 8.7 & 39.4 & 0.3 & 55.6 & 1.3 & 67.5 & 0.9 \\
\hline & & 58.3 & 0.5 & 50.4 & 0.7 & 76.1 & 1.0 & 90.8 & 1.3 \\
\hline
\end{tabular}


Differences in the vibration frequencies of individual shapes are due to the number and height of the pillars, as well as the properties of vibroinsulators and the landing plate masses. Truss structures are usually characterized by a higher than in the monolithic structures vibration damping coefficient, but the above comparison shows that the free vibrations of these structures are similarly damped.
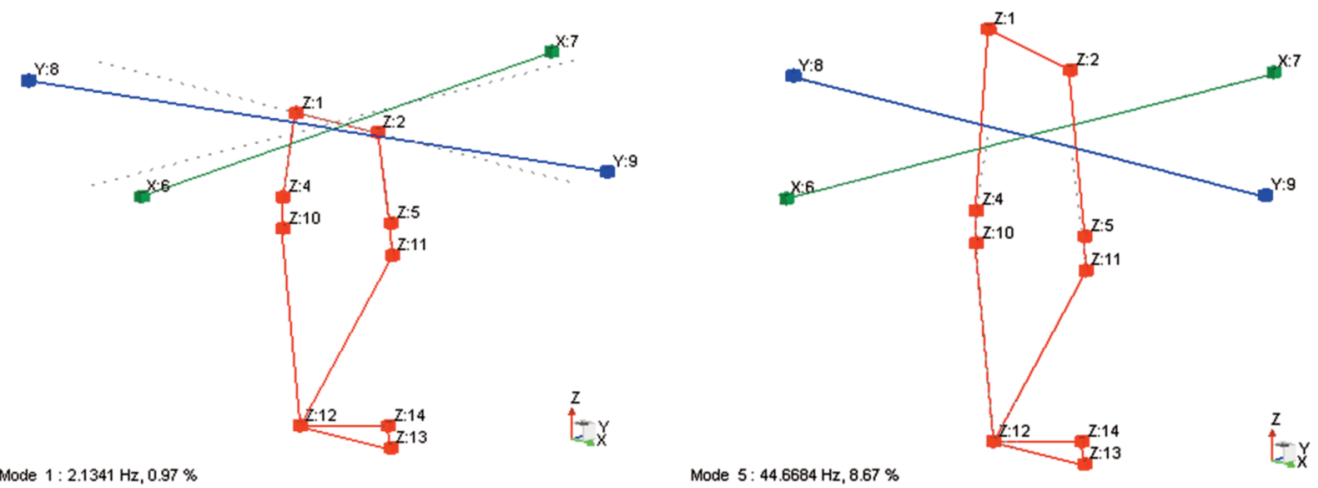

Mode $1: 2.1341 \mathrm{~Hz}, 0.97 \%$

Fig. 6. Examples of measured vibrations shape of the helipad S1.

a)

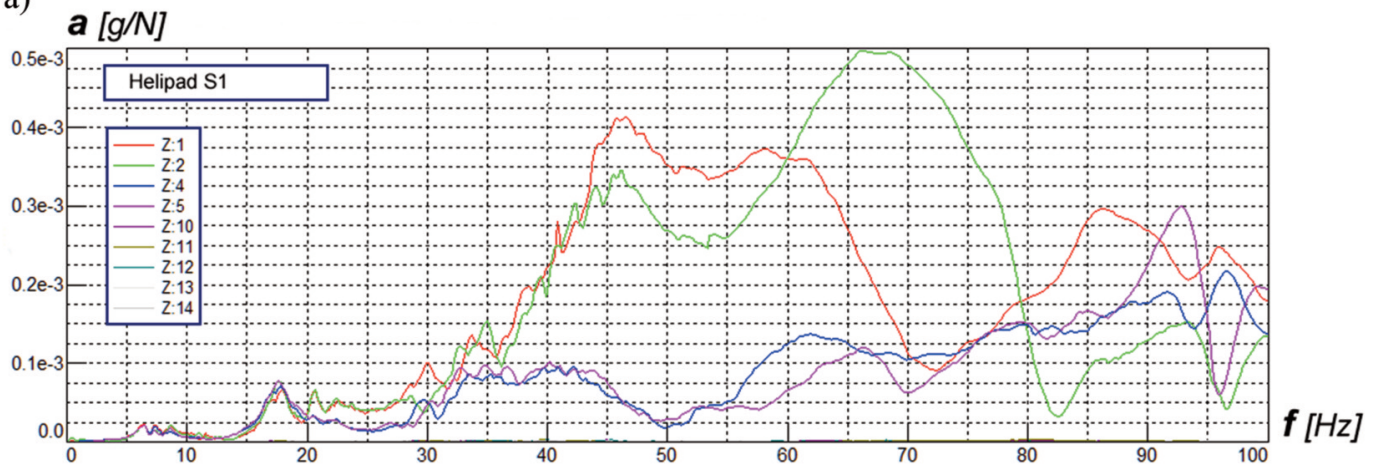

b)

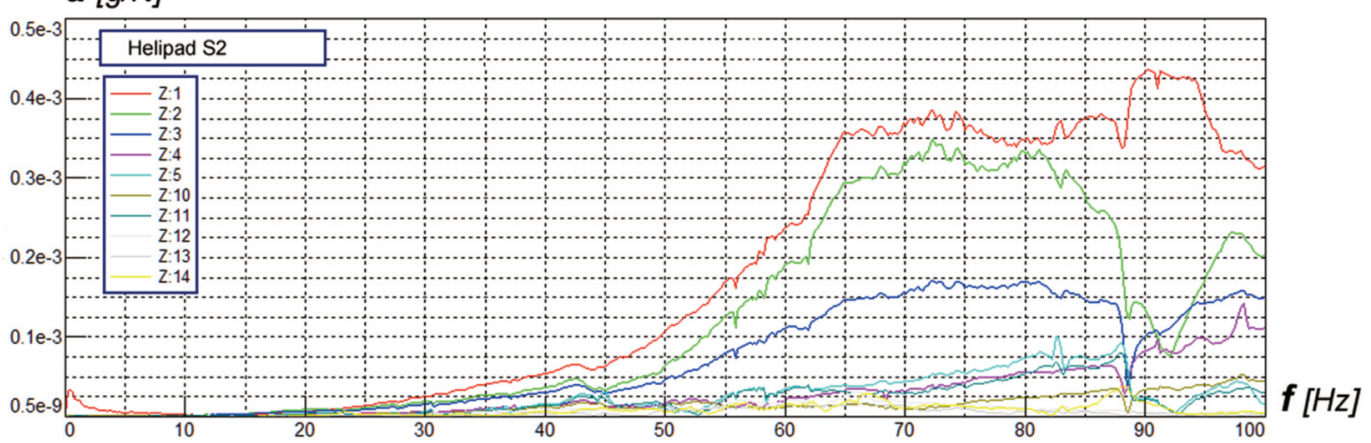

Fig. 7. Amplitude characteristics from sensors located in the middle of the landing plate and lower storeys, a-helipad S1, b-helipad S2.

Measurements of the transfer of vibrations from the helipad to the lower storeys of the building were carried out on the premises of hospitals, as well as in the building undergoing the process of equipping 
and with the courtesy of the hospital management - in rooms almost ready for use. In all of these cases the helipads were completed. The sensors were placed on the floors indoors under the helipad and on the two highest storeys of the building in the vertical axis of the helipad and in the middle of the adjacent rooms. For steel-based helipads the distribution of sensors was assumed as in Fig. 4a. The amplitudefrequency characteristics obtained from the recording of the sensor signals received after the pulse excitation (caused by the use of the modal hammer) in the middle of the landing plate are presented in Fig. 7. Each characteristic is the averaged measurement result for five hammer impacts at the same point. The graphs are shown in unit $[\mathrm{g} / \mathrm{N}]$ which enables to compare the results for hammer impacts with various force.

Basing on the graphs in Figure 7a. it can be concluded that due to the use of vibroinsulators in the pillar bases of the helipad S1, the vibration level recorded by sensors No. 10 - 14 is very small.

In the case of the helipad S2 (Fig. 7b), a small part of the vibrations is transferred from the landing plate to the lower storeys where they are subsequently suppressed and do not show individual resonances. Sensor No. 3 was located on the beam between the pillars with sensors No. 1 and 2.

The final verification of the vibration level in the building can only be carried out during the takeoff and landing of the helicopter, however, their practical execution involves a temporary disruption of the hospital's activities. The measurements require a special landing of the helicopter, as well as the placement of the sensors in places (i.e. rooms) requiring asepsis (e.g. operating rooms) or rooms with specialized analysis equipment.

Figure 8 shows graphs of signals received from sensors during a helicopter landing on the helipad S1 and covers the time from the helicopter's approach to the helipad to the rotor stop. The stroke of the helicopter's skids over the landing plate occurred in 78. second of the recorded signal.

a)

a [g]

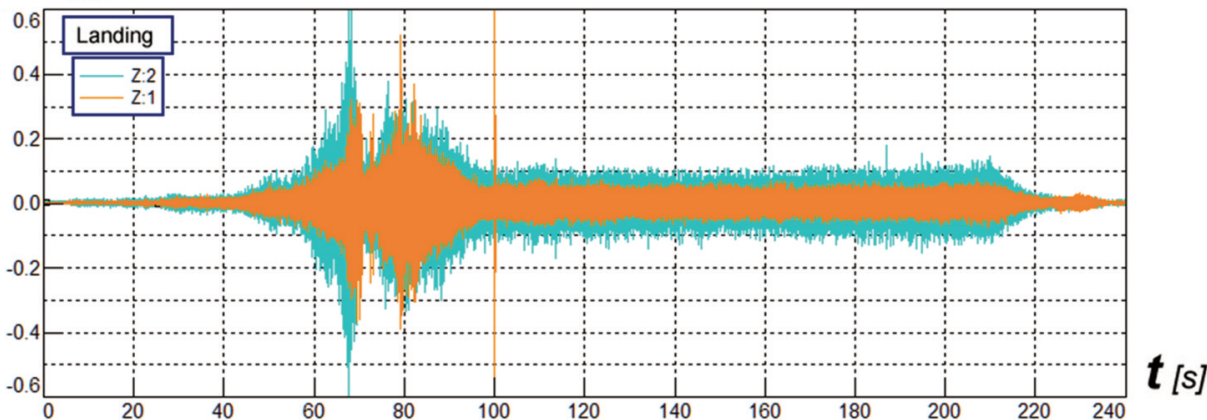

b)

a [g]

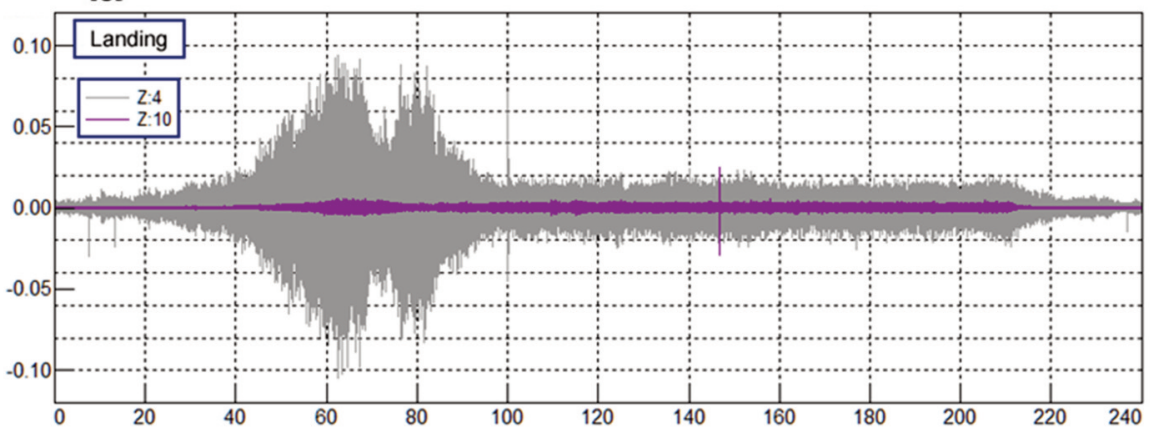

Fig. 8. Sensor signals diagrams during a helicopter landing on the helipad S1 ( $a-b)$. 
c)

a [g]

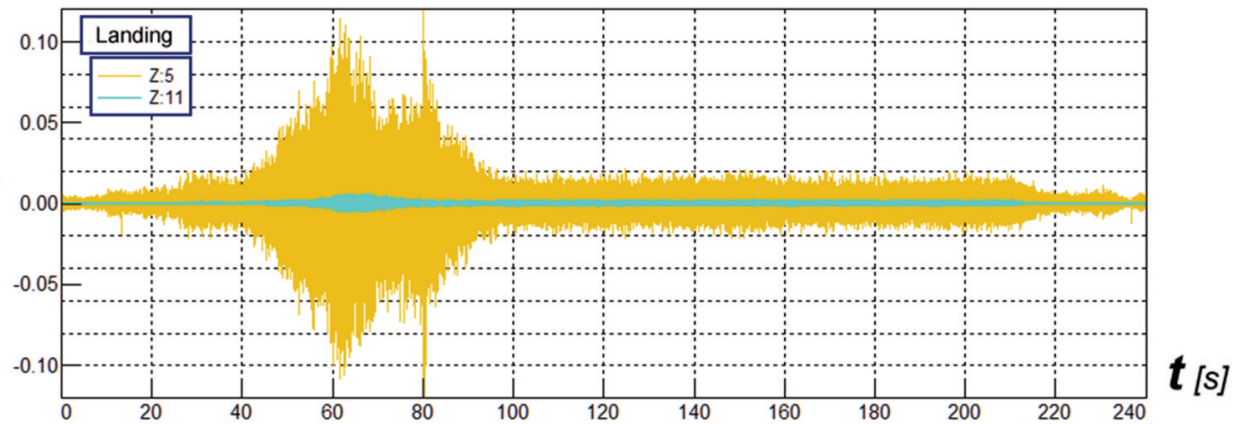

d) $\mathbf{a}[g]$

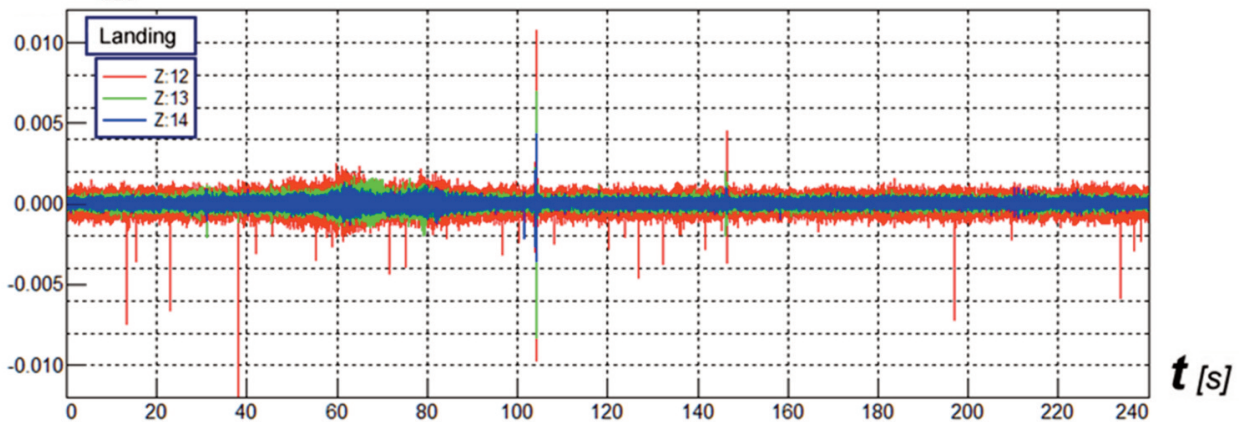

Fig. 8. Sensor signals diagrams during a helicopter landing on the helipad S1 (c-d).

The graphs in Figure 8b and c represent the difference between the signals recorded on both sides of the vibroinsulator at the base of the central columns. The signal waveforms show decrease about 10 times in vibration levels, which indicates the effectiveness of vibroinsulators. The level of recorded vibrations on the lower floor (Fig. $8 \mathrm{~d}$ ) is approx. $0.01 \mathrm{~m} / \mathrm{s} 2(0.001 \mathrm{~g})$. The individual 'peaks' of the signal were of acoustic origin, because the recorded signal was sampled at a frequency of approx. 25600 samples/sec.
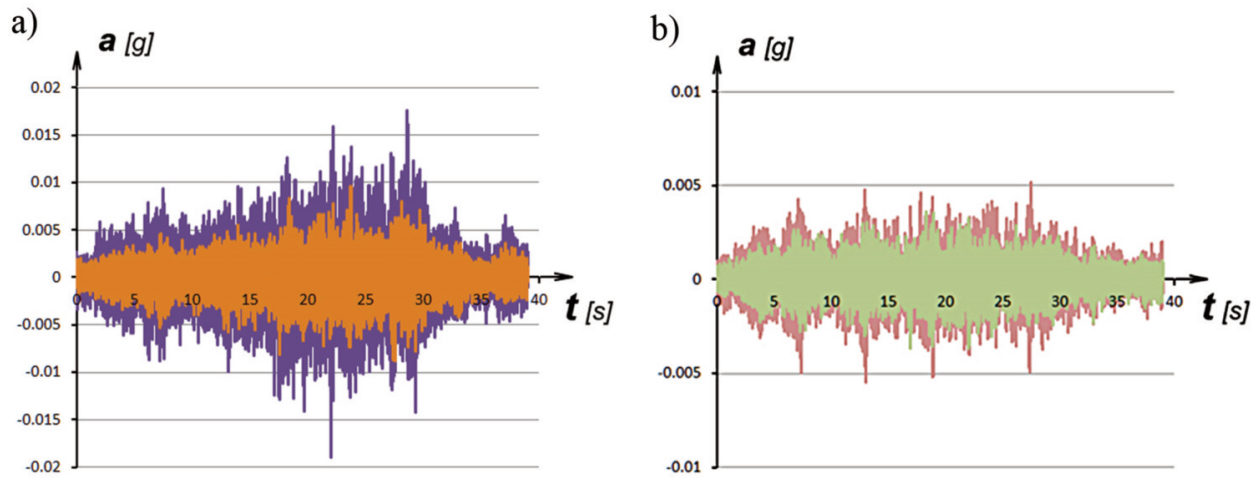

Fig. 9. Sensor signals diagrams during a helicopter landing on the helipad S2,

$\mathrm{a}-$ signal from sensors 4 and $10, \mathrm{~b}$ - signal from sensors 12 and 13 . 
Figure 9 shows graphs of signals from sensors during the landing of the helicopter on the helipad S2. The vibration level from the sensors at the base of the middle column (Fig. 9a) indicates a low vibroinsulation efficiency, but the vibration level on the lower floor (Fig. 9b) is approx. 3 times higher than on the floor of the building under the helipad S1.

A separate threat to the helipad, the building, patients and hospital staff are emergency conditions, such as the helicopter's crash on the landing plate or vibrations caused by turbulence from strong winds.

\section{CONCLUSIONS}

1. The measurements allowed to obtain information about the vibration properties of helipads of different structures, located above the buildings.

2. In order to be able to design a helipad that meets expectations and standards compliance with the standards shall be taken into account in advance and appropriate data are needed on the impact of helicopters or on the method of verifying the vibration properties of the helipad.

3. The measurements confirmed the effectiveness of vibroinsulators, which significantly reduced the transmission of vibrations to the lower storeys of the building.

4. The final verification of the impact of the helicopter on the helipad structure and the hospital building is the analysis of the signal from multiple sensors during the landing and take-off of the helicopter.

5. An important complement would be to conduct vibration studies of the landing site structure during the stronger wind and to assess the level of turbulence-induced vibrations.

\section{REFERENCES}

[1] Act from 8.09.2006 r. about National Medical Rescue (J. of L. 191 No. 1410).

[2] Regulation of the Min. of Health. 27.06.2019 on the hospital emergency department (J. of L. 2019 No. 1213).

[3] Federal Aviation Administration, US Department of Transportation, 2012, Heliport Design -AC 150/5390-2c, Chapter 4 - Hospital Heliports.

[5] Wąchalski, K., 2016, Assessment of the current construction conditions for elevated helipad on hospital buildings in Poland (in Polish), Transactions of the Institute of Aviation No. 3(244), pp. 189-201. 10.5604/05096669.1223423.

[4] Polish Standard PN-B-02171_2017. Assessment of the effects of vibration on people in buildings (in Polish).

[6] Cieślak, S. and Krzymień, W., 2019, Initial analysis of helicopter impact on hospital helipads, Transactions of the Institute of Aviation 3(256), pp. 14-23. 10.2478/tar-2019-0014.

[7] Krzymień, W. and Cieślak, S., 2020, Investigation of the Vibration Properties of Concrete Elevated Hospital Helipads, Vibrations in Physical Systems, No. 31, pp. 1-10. 


\title{
WŁAŚCIWOŚCI DRGANIOWE PRZYSZPITALNYCH LACDOWISK WYNIESIONYCH O KONSTRUKCJI STALOWEJ
}

\begin{abstract}
Abstrakt
Śmigłowce Lotniczego Pogotowia Ratunkowego (LPR) ułatwiają szybki transport pacjentów do dużych szpitali. Wymagania przestrzeni wokół lądowiska jak i bezpieczeństwo wykonywania lotów powodują, że przy szpitalach położonych bliżej centrów miast powstaje więcej lądowisk wyniesionych niż naziemnych. Lądowiska wyniesione mogą mieć różnorodną konstrukcję oraz usytuowanie w zależności od możliwości jakie stwarzają zabudowania szpitalne i ich otoczenie.

Laboratorium Wibroakustyki Instytutu Lotnictwa wykonało pomiary właściwości drganiowych kilku lądowisk wyniesionych. Badania te miały na celu określenie właściwości drganiowych samego lądowiska oraz przenoszenia się drgań wzbudzanych przez lądujący i startujący śmigłowiec na konstrukcję lądowiska, budynku oraz jego wyposażenie.

W artykule przedstawiono niektóre wyniki pomiarów drgań lądowisk o konstrukcji stalowej wzbudzonych młotkiem tzw. modalnym a także przez lądujący i startujący śmigłowiec oraz porównanie ich właściwości drganiowych z lądowiskami o konstrukcji betonowej.
\end{abstract}

Słowa kluczowe: lądowiska wyniesione, badania naziemne, pomiary drgań. 